\title{
Evaluasi Kesiapsiagaan Sekolah Menengah Atas di Kabupaten Pekalongan dalam Penyediaan Mutu dan Inklusivitas Pembelajaran Pasca Pandemic
}

\author{
Susanto ${ }^{1}$, M.Fajru Sidqi ${ }^{2}$, Dwi Ario Fajar ${ }^{3}$ \\ 1,2,3 Program Studi Pendidikan Bahasa Inggris, Universitas Pekalongan \\ E-mail: susanto.unikal@gmail.com
}

Article History: Received: 2022-01-11 || Revised: 2022-02-01 || Published: 2022-02-08

Sejarah Artikel : Diterima: 2022-01-11 || Direvisi: 2022-02-01 || Dipublikasi: 2022-02-08

\begin{abstract}
This research is motivated by the uncertainty of the end of pandemic which leads to students at risk of learning loss and lowering learning quality in school. Therefore, schools must always be ready with a new education system that is different from the previous education system. The pandemic response school education system (Resilience Education System) is one of the right solutions for providing education during the pandemic and post-pandemic period. This research is an evaluative research that aims to reveal the readiness of schools especially in the aspect of teaching and learning towards the Resilience Education System and provide recommendations to schools and policy makers to find out the map of school preparedness during the pandemic and post-pandemic period. The research setting is in a public high school in Pekalongan Regency. The research subjects were school leaders who were taken as a sample. Data were collected by means of questionnaires and interviews and the results of data collection were analyzed qualitatively descriptively. The result shows that schools are not quite ready to manage online learning systems, especially in increasing active involvement in online learning, involving families and communities in online learning, and increasing digital literacy and independent learning.
\end{abstract}

Keywords: Learning Evaluation, Resilience, Education System

\section{Abstrak}

Penelitian ini dilatarbelakangi oleh ketidakpastian berakhirnya pandemi Covid-19 yang berdampak pada ancaman siswa menjadi putus belajar dan menurunnya kualitas pembelajaran. Oleh karena itu, sekolah harus selalu siap siaga dengan sistem pendidikan yang baru yang berbeda dengan sistem pendidikan sebelumnya. Sistem pendidikan sekolah Tanggap pandemic (Resilience Education System) menjadi salah satu solusi tepat untuk penyelenggaraan pendidikan di masa pandemic dan masa pasca pandemic. Penelitian ini adalah penelitian evaluasi yang bertujuan untuk mengungkapkan kesiapan dari sekolah menuju Resillence Education Sistem terutama dalam aspek pembelajaran dan memberikan rekomendasi kepada sekolah dan pemangku kebijakan untuk mengetahui peta kesiapsiagaan sekolah di masa pandemic dan pasca pandemic. Seting penelitian di SMA negeri di Kabupaten Pekalongan. Subjek penelitiannya adalah para pimpinan sekolah yang diambil sebagai sampling. Data dikumpulkan dengan cara kuisioner dan interview dan hasil dari pengumpulan data dianalisis secara kualitatif deskriptif. Hasil penelitian ini menunjukkan bahwa sekolah belum cukup siap untuk mengelola sistem pembelajaran daring terutama dalam peningkatan keterlibatan aktif dalam pembelajaran daring, pelibatan keluarga dan masyarakat dalam pembelajaran daring, dan peningkatan literasi digital dan pembelajaran mandiri.
\end{abstract}

Kata kunci: Evaluasi Pembelajaran, Resillence, Education System

\section{PENDAHULUAN}

Pandemic Covid-19 yang melanda dunia dan berdampak bagi berbagai sektor kehidupan termasuk pendidikan. Ketidaksiapan dalam menghadapi pandemic Covid-19 yang begitu mengagetkan pada dunia pendidikan tampak dari berbagai penelitian yang mengevaluasi ketidaksiapan sector pendidikan pada masa Covid-19. Ameli, A., Hasanah, U., Rahman, H., \& Putra, A. M. (2020) menemukan bahwa pembelajaran online pada masa pandemik kurang efektif terutama disebabkan oleh faktor kurangnya sarana dan prasarana serta ketidaksiapan edukasi teknologi. 
Ketidaksiapan ini berpotensi maningkatakan disparitas atau kesenjangan dalam pendidikan di Indonesia (Santosa,2020), walaupun pandemi covid diprediksi akan berakhir dengan ditemukan dan digalakkannya program vaksin di Indonesia, kesiagaan terhadap pandemi di masa depan tetap perlu dilakukan. Apalagi corona virus merupakan sejenis virus flu yang mempunyai kemampuan mutasi yang hebat. Sampai saat ini saja sudah ada empat varian seperti varian Alfa, Beta, Gamma, Delta, Lambda, Kappa dan Mu. Oleh karena itu, andaikata sekolah sudah diperbolehkan tatap muka pun, sekolah tetap dituntut untuk menerapkan protocol kesehatan new nomal (kebiasaan baru).

Situasi yang penuh ketidakpastian tersebut menuntut perencanaan pendidikan yang tidak mudah. Resiko menurunnya peserta didik, stress dan depresi hingga menurunnya indeks sumber daya manusia pun dihadapan mata. Oleh karena itu, dibutuhkan suatu kesiapsiagaan untuk mempersiapkan dunia pendidikan ke depan yang lebih baik. Dari pengalaman pendidikan di era Covid dengan berbagai ketidaksipan tersebut, hendaknya kita belajar untuk mempersiapkan ke depan dengan lebih baik. Di dunia Pendidikan, kesiapsiagaan ini dibangun melalui sistem pendidikan tangguh (resilience education system) pasca pandemi Covid-19, walaupun demikian, dengan meningkatnya jumlah masyarakat yang telah divaksin dan turunnya jumlah pasien positif serta tingkat kematian, pembelajaran tatap muka sudah mulai bisa dilaksanakan. Selain itu, penurunan tren positif dan kematian karena covid-19 ini juga berdampak pada penurunan Kabupaten dan kota Pekalongan masuk PPKM level 2 atau zona kuning sehingga kegiatan pertemuan tatap muka di sekolah sudah dapat diberikan ijin dengan tetap memperhatikan protokol kesehatan.

Penelitian ini bertujuan untuk mengukur kesiapsiagaan sekolah menengah atas di Kabupaten Pekalongan menuju sistem pendidikan tangguh pasca Pandemi Covid-19. Sekolah tangguh khususnya dari pilar kualitas dan inklusivitas pembelajaran sebagai salah satu indikator utama sekolah tanggu pasca pandemi disamping 3 (tiga) pilar lain (1) akses pelayanan pendidikan, (2) kesejahteraan mental dan dukungan psikososial dan (3) keamanan sekolah. Indikator Kualitas dan inklusivitas dipilih mengingat ancaman putus belajar begitu besar terutama di daerah Kabupaten Pekalongan yang secara geografis sebagian besar adalah daerah pegunungan yang bermasalah dalam sinyal internet. Selain ancaman putus belajar, ketidaktersediaan jaringan internet ini juga menyebabkan ancaman diskriminasi terhadap siswa yang tidak mempunyai gawai dan tinggal di daerah yang tidak ada sinyal internet.

Dari latar belakang yang telah dijabarkan di atas, maka permasalahan dalam penelitian ini dapat dirumuskan sebagai berikut: 1. Bagaimana tingkat kesiapsiagaan Sekolah Menengah Atas (SMA) di Kabupaten Pekalongan dalam penyediaan mutu dan inklusivitas pembelajaran pasca pandemic menuju sistem pendidikan tangguh (resilience education system) pasca pandemi covid-19? 2. Apa rekomendasi untuk menjaga mutu dan inklusivitas pembelajaran pasca pandemi menuju sistem pendidikan tangguh (resilience education system) pasca pandemic covid-19 di Kabupaten Pekalongan?.

\section{METODE PENELITIAN}

Penelitian ini adalah penelitian deskriptif evaluative yang dilakukan untuk melakukan evaluasi dan mendeskripsikan variabel kualitas dan inklusivitas pembelajaran. Data diperoleh memalui interview dan kuisioner. Kuisioner disusun dengan pertanyaan tertutup dan menggunakan skala likert. Interview dilakukan untuk mendapatkan informasi yang mendalam sebagai tindak lanjut dari informasi yang didapat dari kuisioner. Sumber data dari penelitian ini ada dua yaitu data primer dan data sekunder. Data primer merupakan hasil data yang diperoleh dari instrumen penelitian yang disebarkan kepada responden (Sugiyono, 2010: 45). Data utama diperoleh dari lembar kuisioner dan interview dengan melibatkan Pimpinan Sekolah, dan Guru sebagai narasumber. Data sekunder berasal dari referensi-referensi pustaka atau dokumen yang 
mendukung data primer (Stufflebeam, 2012: 23). Data Sekunder diperoleh dari hasil-hasil karya ilmiah yang berkaitan dengan permasalahan yang sedang diteliti. Dalam penelitian ini, metode yang digunakan adalah metode Purposive Sampling. Metode Purposive Sampling adalah cara pengambilan subyek penelitian yang didasarkan pada suatu tujuan tertentu. Dalam penelitian ini, subyek penelitian adalah pimpinan pengelola Sekolah Menengah Atas di Kabupaten Pekalongan terutama di daerah dengan siswa yang rawan terancam putus belajar karena ketiadaan gawai maupun sinyal internet. Metode Analisis Data digunakan dalam penelitian ini adalah metode deskriptif kualitatif. Tujuan analisis data kualitatif ini adalah untuk menggali makna, menggambarkan, menjelaskan dan menempatkan data pada konteksnya masing masing (Arikunto \& Jabar, 2014:165). Adapun proses analiss data melibatkan reduksi data dari data yang telah dikumpulkan dengan cara memfokuskan pada hal hal yang pokok atau penting sesuai dengan tujuan evaluasi program. Setelah dipilih data data yang penting, kemudian data ditafsirkan menggunakan analisis konten sehingga hasil analisis ini memberikan kesimpulan yang kemudian dipresentasikan sesuai dengan keategori dan pokok permasalahan yang dibuat.

\section{HASIL DAN PEMBAHASAN}

A. Tingkat Mutu dan Inklusivitas Pembelajaran Sekolah Menengah Atas (SMA) Di Kabupaten Pekalongan

Dari beberapa sekolah yang disurvei menujukkan bahwa kesiapan sekolah menuju sistem pendidikan tangguh terutama pada aspek pembelajaran yang mencakup dimensi Adaptasi perubahan, Fleksibilitas dan Keadilan penilaian pembelajaran, manajemen pemulihan pembelajaran, kurikulum, pengajaran, Pengajaran dan Pembelajaran, sistem Pembelajaran Jarak Jauh dan Daring, Pelibatan Orang Tua dan Masyarakat dan Peningkatan Kapasitas Guru dan Sekolah. Adapun rinciannya sebagai berikut:

1. Adaptasi perubahan

Aspek ini mencakup kesiapan sekolah dalam masa menyesuaikan diri dengan kondisi pandemi dan pasca pendemi terutama dalam hal ujian akhir dan penilaian. Ujian akhir dilaksanakan secara daring dengan pemberian tugas yang dapat dikumpulkan secara daring dan luring ke sekolah. Untuk siswa yang mengalami kesulitan dalam akses internet, sekolah memperbolehkan siswa untuk menggunakan fasilitas internet sekolah untuk mengerjakan ujian. Beberapa siswa menggunakan fasilitas ini untuk mengerjakan ujian tetapi tidak untuk aktivitas pembelajaran.

2. Fleksibilitas dan Keadilan penilaian pembelajaran,

Aspek ini mencakup monitoring pembelajaran, strategi penilaian pembelajaran, dan evaluasi pembelajaran. Dalam monitoring pembelajaran terutama dalam keterlibatan aktif dalam pembelajaran daring, sekolah mengevaluasi melalui laporan dari guru pada rapat evaluasi semester. Guru mengeluhkan kepasifan siswa dalam keterlibatan dalam pembelajaran baik dalam pembelajaran maupun dalam pengumpulan tugas dan latihan, dalam hal penilaian, pembelajaran sekolah memprioritaskan penilaian formatif melalui nilai latihan dan tugas, walaupun ujian tengah dan akhir masih tetap dilaksanakan. Latihan dan penugasan dihimbau tidak memberatkan siswa walaupun dalam praktiknya, masih ada guru yang hanya mengandalkan pemberian tugas dan kurang dalam memberikan penjelasan dalam bentuk video rekaman atau resources dari sumber lain yang dapat digunakan siswa untuk belajar secara mandiri.

3. Manajemen pemulihan pembelajaran

Aspek ini mencakup penyesuaian kalender akademik dan dukungan kepada siswa yang terdampak untuk mengejar ketertinggalan siswa dalam pelajaran. Dalam penyesuaian 
kelender akademik, sekolah telah melakukan beberapa penyesuaian dengan mengkonsultasikan dengan komite sekolah.

4. Pengajaran dan Pembelajaran

Aspek pengajaran dan pembelajaran mencakup kurikulum dan metode pengajaran. Dalam sisi kurikulum, semua sekolah sampel melakukan relaksasi kurikulum 2013 atau kurikulum darurat sesuai dengan perintah kementrian pendidikan dan kebudayaan. Berdasarkan revisi surat keputusan bersama (SKB) Empat Menteri yang telah diterbitkan tanggal 7 Agustus 2020, pemerintah telah mengeluarkan berbagai kebijakan dan inisiatif untuk menghadapi kendala pembelajaran di masa pandemi Covid-19. Kurikulum darurat yag diterapkan oleh satuan pendidikan dalam kondisi khusus memberikan fleksibilitas bagi sekolah untuk memilih kurikulum yang sesuai dengan kebutuhan pembelajaran peserta didik. Kurikulum darurat yang telah disiapkan oleh Kemendikbud merupakan penyederhanaan dari kurikulum nasioanal. Satuan pendidikan pada kondisi khusus dalam pelaksanaan pembelajaran dapat 1) tetap mengacu pada Kurikulum Nasional; 2) menggunakan kurikulum darurat; atau 3) melakukan penyederhanaan kurikulum secara mandiri.

Prinsip kebijakan pendidikan di masa pandemi Covid19 adalah mengutamakan kesehatan dan keselamatan siswa, pendidik, tenaga kependidikan, keluarga, dan masyarakat secara umum, serta mempertimbangkan tumbuh kembang siswa dan kondisi psikososial dalam upaya pemenuhan layanan pendidikan selama pandemi Covid-19. Selain itu, sekolah diberi fleksibilitas untuk memilih kurikulum yang sesuai dengan kebutuhan pembelajaran siswa di masa pandemi, sebagaimana ditetapkan dalam Keputusan Menteri Pendidikan dan Kebudayaan terkait kurikulum pada masa darurat. Dalam relaksasi kurikulum, kurikulum yang di terapkan selama masa pandemi yaitu Kurikulum 2013 dengan KD dan KI darurat COVID 19. Sesuai dengan pedoman pemerintah dalam masa pandemi dapat menggunakan kurikulum yang sesuai dengan kebutuhan pembelajaran peserta didik. Kurikulum darurat masa pandemi COVID 19 memberikan fleksibilitas tinggi sekolah untuk memilih kurikulum yang sesuai dengan kebutuhan pembelajaran siswa. Penggunaan Kurikulum Darurat COVID 19 di SMA terlaksana dengan baik melalui penyederhanaan kompetensi dasar pelajaran sehingga guru dan siswa dapat berfokus pada kompetensi esensial dan kompetensi prasyarat untuk kelanjutan pembelajaran di tingkat selanjutnya. Dalam masa pandemi Kurikulum yang dipilih diharapkan tidak membebani siswa dengan tuntutan capaian kurikulum.

Pelaksanaan kebijakan pemerintah di atas juga diwujudkan dalam bentuk implementasi pembelajaran jarak jauh (PJJ) dan dikombinasikan dengan Pertemuan Tatap Muka (PTM) terbatas dengan mempertimbangkan protokol kesehatan seperti siswa dan guru sudah divaksin, memakai masker dan jaga jarak sertasatu kelas diisi 50\% dari total kapasitas. Akan tetapi pelaksanaan kebijakan kombinasi tersebut berbeda antar sekolah sampel. Di beberapa sekolah seperti SMA N 1 Doro, SMA N 1 Bojong, dan SMN N 1 Kedungwuni PTM terbatas yang dilakukan kepada $30 \%$ dari jumlah siswa dan $70 \%$ siasnya dilakukan dengan PJJ sedangkan di sekolah yang lain SMA N 1 Wiradesa dan SMA PGRI 2 Kajen 50\% PTM terbatas dan 50\% sisanya PJJ. Adapun pembagian jadwal, semua sekolah sampel melaksanakan PTM terbatas dilakukan pada jam ke 1-6 dan PJJ dilakukan pada jam ke 7-10. Relaksasi kurikulum sudah disosialisasikan kepada pemangku kepentingan baik guru, siswa, tendik, orang tua murid maupun Dinas Pendidikan.

Walaupun demikian, Priotitas ini kurang mempertimbangkan kebutuhan siswa akan rekreasi, bermain, berolahraga dan kegiatan kreatif. Dalam masa pandemik dan berbagai 
level, kegiatan olahraga dihentikan. Kegiatan di sekolah yang diijinkan hanya terbatas pada pengumpulan tugas atau pertemuan kelas terbatas dan akses internet bagai siswa yang kesulitan. Tidak ada ekstrakurikuler baik minat bakat maupun olah raga yang diijinkan.

Materi pembelajaran telah tersedia untuk semua siswa secara daring. Guru menyediakan materi dan mengirimnya melalui google classroom atau whatsapp group. Adapun bentuk materi dengan format dokumen, video atau audio. Akan tetapi, file video belum diatur sedemikian rupa terutama dalam hal durasi sehingga tidak terlalu besar dan materi dapat tersampaikan secara efektif.

Evaluasi dan refleksi perubahan kurikulum dilakukan dalam satu tahun ajaran. Selain itu evaluasi dilakukan dengan konsideran kebijakan pemerintah terbaru sesuai dengan perkembagan kasus infeksi virus local, dalam aspek metode pengajaran, guru secara fleksibel menyesuaikan pengajaran sesuai kebutuhan siswa. Sebagaimana dikemukakan di atas, penerapan kebijakan pemerintah memberikan kebebasan kepada guru untuk memilih kurikulum sesuai dengan kebutuhan siswa. Walaupun demikian, pembelajaran yang dilaksanakan belum memberikan prioritas pembelajaran mandiri berbasis ketertarikan dan kebutuhan siswa.

Pembelajaran kolaboratif berbasis daring belum secara maksimal dilaksanakan karena kemampuan sumber daya. Materi pengajaran dan metode pengajaran belum meakukan integrasi dengan kegiatan dalam rumah maupun masyarakat. Pembelajaran sejawat, kelompok maupun mentoring sejawat dan beda kelas juga tidak bisa dilaksanakan secara maksimal, Materi sampai kepada siswa tetapi tidak ada monitoring keterlibatan siswa dalam pembelajaran. Kendala internet dan jaringan menjadi masalah utama tetapi beberapa sekolah telah mengambil kebjakan untuk mengijinkan siswa ke sekolah menggunakan fasilitas internet sekolah seperti di laboratorium computer terutama bagi siswa yang tidak terjangkau sinyal atau keterbatasan alat telefon genggam atau laptop. Akan tetapi, kebijakan tersebut tidak berjalan baik karena tidak banyak direspon oleh siswa. Bahkan tidak ada siswa yang memanfaatkan kebijakan tersebut kecuali pada saat ujian.

Kesesuaian dengan harapan siswa belum terukur karena tidak ada survei resmi tentang kepuasan pembelajaran kepada siswa. Dari hasil wawancara dengan siswa, beberapa mengeluhkan ketidakpahaman dengan materi yang disampaikan melalui video karena terlalu singkat, Pembelajaran daring sudah terlaksana dengan baik akan tetapi keamanan digital dari peretasan belum dilakukan.

5. Pembelajaran Jarak Jauh dan Daring

Semua sekolah melaksanakan pembelajaran daring menggunakan LMS sesuai dengan pilihan guru. Mayoritas guru menggunakan Google Classroom dikombinasikan dengan Whatsapp group. Google Classroom dipakai untuk mengirimkan materi dan penugasan sedangkan Whatsapp group digunakan untuk meningkatkan interaksi antara guru dan siswa mengingat lemahnya sinyal internet sehingga tidak memungkinkan interaksi menggunakan aplikasi video conference seperti zoom atau gmeet berjalan lancer, selain tidak meratanya tingkat keterjangkauan sinyal internet, keaktifan dan control terhadap siswa juga menjadi hambatan dalam pembelajaran. Hampir semua guru mengeluhkan tentang tingkat keterlibatan aktif dalam pembelajaran dan ketepatan waktu dalam pengumpulan tugas atau latihan oleh siswa masih sangat rendah dan guru tidak bisa mengontrolnya. Oleh karena itu, pembelajaran daring tidak menjadi prioritas pengembangan ke depan. Pembelajaran tatap muka tetap menjadi prioritas untuk pembelajaran pasca pandemi. 
Kurangnya prioritas sekolah terhadap pengembangan pembelajaran daring dan jarak jauh ini membawa konsekuensi terhadap kurangnya usaha peningkatan kemampuan digital, kemampuan belajar mandiri dan sikap kemandirian dalam pembelajaran daring dan jarak jauh. Kemampuan siswa untuk belajar mandiri mengeksplor sumber-sumber belajar dan sikap kesadaran dan tanggungjawab diri masih sangat rendah sehingga pembalajaran daring menjadi terhambat.

6. Keterlibatan Orang Tua dan Masyarakat

Dalam pembelajaran daring yang dilaksanakan sekolah, peran orang tua dan masyarakat telah diwakili oleh komite sekolah. Program-program sekolah terkait dengan pembelajaran pada masa pandemik disosialisasikan kepada komite sekolah setiap pertemuan dengan komite sekolah. Aspirasi orang tua dan masyarakat juga diwadai dalam pertemuan dengan dengan komite sekolah, walaupun demikian, peran orang tua dan masyarakat belum begitu maksimal dalam mendampingi dan memfalisitasi pembelajaran siswa. Pengawasan orang tua dan masyarakat tidak dapat berjalan secara maksimal mengingat tidak semua orang tua tidak mempunyai waktu mendampingi siswa dan hanya mengingatkan belajar anaknya, selain itu, peran serta masyarakat terutama organisasiorganisasi kemasyarakat masih kurang mengingat pembelajaran belum terintegrasikan dan cenderung terpisah dari kegiatan kemasyarakatan.

\section{Peningkatan Kapasitas Guru dan Sekolah}

Kemampuan teknologi pembelajaran guru belum merata dan cenderung kurang terutama guru guru senior. Oleh karena itu, sekolah maupun dinas mengadakan pelatihanpelatihan untuk guru tertutama dalam penggunaan teknologi pembelajaran seperti LMS Google classroom, Moodle dan aplikasi untuk interaksi dalam pembelajaran seperti Zoom, Gmeet dan Whatapp Grup, akan tetapi, pelatihan guru masih terbatas pada penggunaan teknologi pembelajaran dan belum menyentuh pada aspek metode dan penilaian pembelajaran daring, perkembagnan sosio emosional siswa, kompetensi digital dan isu kesejahteraan dan kesehatan mental siswa.

B. Rekomendasi Untuk Menuju Sistem Pendidikan Tangguh (Resilience Education System) Pasca Pandemic Covid-19 Di sekolah Kabupaten Pekalongan?

Dari hasil temuan survei sebelumnya, ada beberapa rekomendasi untuk sekolah yang perlu dilaksanakan yaitu sebagai berikut.

1. Sekolah perlu tetap mengembangkan pembelajaran daring mengingat ketidakpastian pandemi dan tren pendidikan daring global.

2. Pembelajaran perlu mengembangkan kapasitas siswa dalam literasi digital, teknologi dan pembelajar mandiri (autonomous learning)

3. Selain pengembangan kapasitas guru dalam teknologi pembelajaran, guru perlu dikembangkan juga dalam kapasitas tentang metode, strategi dan penilaian pembelajaran daring serta kapasitas tentang kesejahteraan dan kesehatan sosio emosional siswa.

4. Pembelajaran perlu diintegrasikan dengan program dan kegiatan keluarga dan masyarakat sehingga keterlibatan keluarga dan masyarakat untuk pembelajaran siswa di luar sekolah makin tinggi.

5. Selain variasi dan kreativitas penggunaan teknologi pembelajaran, guru juga perlu menggunakan variasi pembelajaran dan penilaian seperti pembelajaran antar siswa baik yang sama tingkatnya atau dengan siswa lain dari tingkat yang lebih tinggi. Oleh karena itu, 
pelatihan untuk peningkatan kapasitas guru dalam metode pembelajaran dan penilaian daring perlu dilakukan.

\section{SIMPULAN DAN SARAN}

\section{A. Simpulan}

Berdasarkan hasil penelitian yang telah dilakukan, maka dapat disimpulkan bahwa sekolah belum cukup siap untuk mengelola sistem pembelajaran daring yang masih berorientasi pada pembelajaran tatap muka tradisional. Oleh karena itu masih muncul keluhan tentang ketidakmampuan mengontrol kelas, keterlibatan aktif siswa dalam pembelajaran daring, pelibatan keluarga dan masyarakat dalam pembelajaran daring, dan peningkatan literasi digital dan pembelajaran mandiri, Paradigma pembelajaran daring yang berbeda dengan pembelajaran tatap muka belum begitu dipahami dan dilaksanakan. Pembelajaran daring menuntut kemandirian dan tanggung jawab siswa dalam belajar, kapasitas guru sebagai fasilitator yang memberikan petunjuk dan arahan serta motivasi bagi siswa untuk mengeksplor berbagai sumber belajar. Selain itu, guru juga perlu untuk menjadi motivator untuk mendorong siswa untuk belajar dan mengatasi segala hambatan selama pembelajaran daring.

\section{B. Saran}

Berdasarkan hasil penelitian yang telah dilakukan, salah satu saran yang dapat dikemukakan oleh peneliti yaitu sekolah bekerjasama dengan dinas terkait dan masyarakat hendaknya tetap memberikan prioritas pada pengembangan pembelajaran daring mengingat situasi pandemic yang belum bisa diprediksi waktu berakhirnya. Peningkatan kapasitas guru dalam pembelajaran daring terutama dalam hal metode, penilaian serta motivasi siswa perlu dilakukan melalui berbagai pelatihan dan seminar yang dipraktekkan dan dimonitoring dalam pembelajaran.

\section{DAFTAR RUJUKAN}

Ameli, A., Hasanah, U., Rahman, H., \& Putra, A. M. (2020). Analisis keefektifan pembelajaran online di masa pandemi COVID-19. Mahaguru: Jurnal Pendidikan Guru Sekolah Dasar, 2(1), 28-37.

Arikunto, Suharsimi \& Cepi Safriddin Abdul Jabar. 2014. Evaluasi Program Pendidikan.Jakarta: Bumi Aksara

Bahri, S. (2020). Pengembangan Teknologi dalam Pendidikan Pascapandemi Covid-19. In Prosiding Seminar Nasional Pascasarjana (PROSNAMPAS) (Vol. 3, No. 1, pp. 517-522).

Bransford, J. D., Brown, A. L., \& Cocking, R. R. (2005). How people learn: Brain, mind, experience and school Retrieved from https://www.nap.edu/catalog/9853/how-people-learn-brain-mindexperience-and-school-expanded-edition

Faliyandra, F., Suarmika, P. E., Hidayat, N., Lestari, S. D., \& Utama, E. G. (2021). DAMPAK NEGATIF MEDIA SOSIAL PASCA COVID-19 PADA SISWA: ANALISIS PERENCANAAN KEPADA SEKOLAH DI SEKOLAH DASAR. JPDI (Jurnal Pendidikan Dasar Indonesia), 6(2), 13-17.

Indrawati, B. (2020). Tantangan dan Peluang Pendidikan Tinggi Dalam Masa dan Pasca Pandemi Covid-19. Jurnal Kajian Ilmiah, 1(1), 39-48.

Kesi, K. (2020). Perubahan Lanskap Pendidikan Dengan PJJ (Pembelajaran Jarak Jauh) Pascapandemi Covid-19. In Prosiding Seminar Nasional Pascasarjana (PROSNAMPAS) (Vol. 3, No. 1, pp. 499-505). 
Nurnina, I. (2021). AFIRMASI MODAL SOSIAL UNTUK MENINGKATKAN PERAN PENDIDIKAN MASA DEPAN (Proyeksi Implementasi Pasca Pandemi Covid-19). Jurnal Sosiologi Nusantara, 7(1), 149-172.

Pujilestari, Y. (2020). Dampak positif pembelajaran online dalam sistem pendidikan Indonesia pasca pandemi covid-19. Adalah, 4(1).

Santosa, A. B. (2020). Potret Pendidikan di Tahun Pandemi: Dampak COVID-19 Terhadap Disparitas Pendidikan di Indonesia. CSIS Commentaries, 1-5.

Stufflebeam,D. 2011. Design in Evaluative Research. Canberra : Canberra Press

Sugiyono. 2010. Metode Penelitian Pendidikan. Pustaka Pelajar : Yogyakarta

Triwiyanto, T. (2020). BUKAN SEKEDAR SUBSIDI PULSA, UNTUK MENGURANGI ANGKA PUTUS SEKOLAH DAMPAK PANDEMI COVID-19. In Seminar Nasional Arah Manajemen Sekolah Pada Masa Dan Pasca Pandemi Covid-19.

Winandi, G. T. (2020). Perencanaan Pendidikan Pada Masa Pasca Pandemi Covid-19. In Prosiding Seminar Nasional Pascasarjana (PROSNAMPAS) (Vol. 3, No. 1, pp. 315-317).Kusumawati, Setiyani. (2017). Aplikasi Pembelajaran Iqro Berbasis Multimedia Pada TK Islam Terpadu Al Mubarak Palu. Jurnal Elektronik Sistem Informasi dan Komputer. Vol.3. No.1. Januari-Juni. 2017. 